\title{
PERSEPSI UKM TERHADAP APLIKASI AKUNTANSI BERBASIS ANDROID DENGAN PENDEKATAN TECHNOLOGY ACCEPTANCE MODEL DAN THEORY OF PLANNED BEHAVIOR
}

\author{
Embun Suryani ${ }^{1}$, Sinta Almanika ${ }^{2}$, Adi Septiawan ${ }^{3}$ \\ ${ }^{1}$ Fakultas Ekonomi dan Bisnis, Universitas Mataram, Indonesia. \\ E-mail:embunsuryani@unram.ac.id \\ ${ }^{2}$ Fakultas Ekonomi dan Bisnis, Universitas Mataram, Indonesia. \\ ${ }^{3}$ Fakultas Ekonomi dan Bisnis, Universitas Mataram, Indonesia.
}

\begin{tabular}{|c|c|}
\hline ARTICLE INFO & ABSTRACT \\
\hline 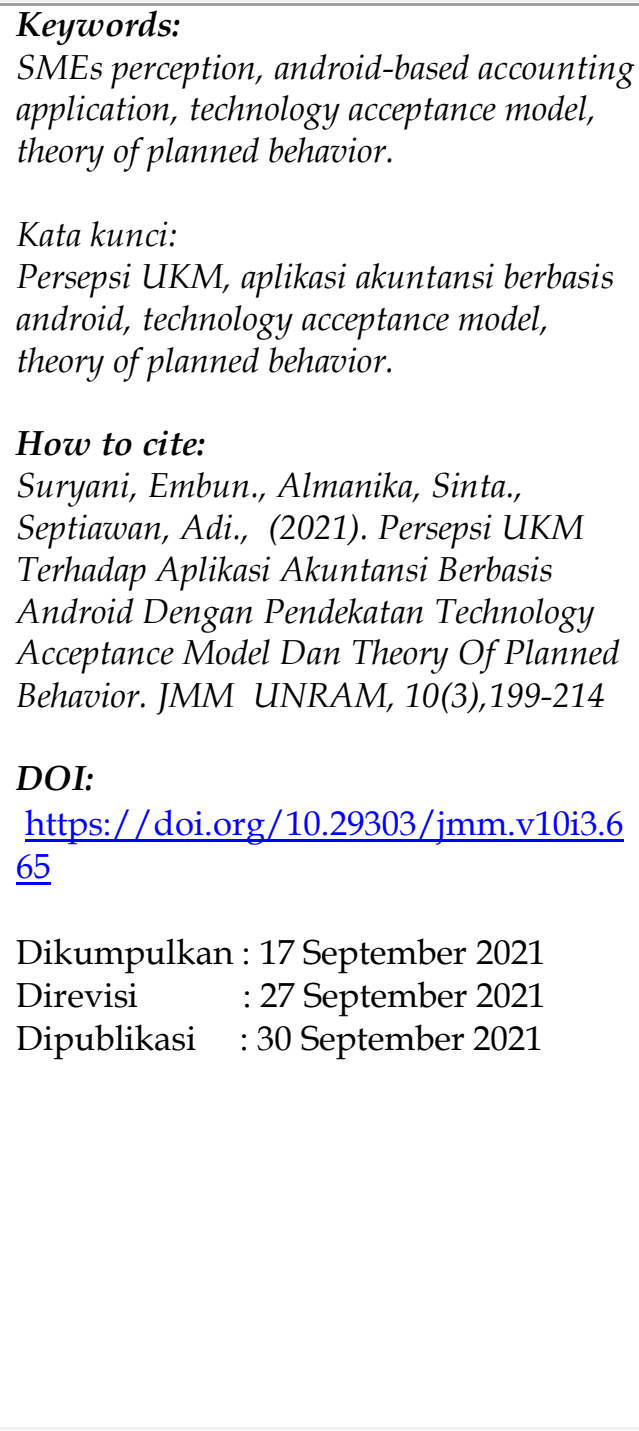 & $\begin{array}{l}\text { The purpose of this study was to determine the } \\
\text { perceptions of Small and Medium Enterprises (SMEs) } \\
\text { users and non-users of Android-based accounting } \\
\text { applications as well as the benefits and feasibility of the } \\
\text { application to be used as an SME accounting } \\
\text { information system. This study uses phenomenological } \\
\text { methods and analyzed descriptively. The data were } \\
\text { analyzed using interactive analysis techniques which } \\
\text { included data collection, data reduction, data } \\
\text { presentation, and drawing conclusions. The results of } \\
\text { this study indicate that the perception of SMEs using } \\
\text { Android-based accounting applications provides a lot } \\
\text { of positive responses, both from application users and } \\
\text { non-users. The results of interviews with informants } \\
\text { prove that android-based accounting applications can } \\
\text { improve business performance and productivity, work } \\
\text { faster, stored data is safer, and the accounting } \\
\text { information produced is clearer, more complete, and } \\
\text { accurate. Although most of the informants gave a } \\
\text { positive response, a few informants were still } \\
\text { comfortable using manual recording because it was } \\
\text { considered easy and did not require complex recording. } \\
\text { From the results of data analysis, the android-based } \\
\text { accounting application has a feasibility level of } 72 \% \\
\text { which indicates that this accounting application is very } \\
\text { feasible to be used as a better financial recording of } \\
\text { SMEs and meets accounting standards. } \\
\text { Tujuan dari penelitian ini adalah untuk } \\
\text { mengetahui persepsi pelaku Usaha Kecil Menengah } \\
\text { (UKM) pengguna dan non pengguna aplikasi } \\
\text { akuntansi berbasis Android serta manfaat dan } \\
\text { kelayakan aplikasi untuk digunakan sebagai sistem } \\
\text { informasi akuntansi UKM. Penelitian ini } \\
\text { menggunakan metode fenomenologi dan dianalisis }\end{array}$ \\
\hline
\end{tabular}




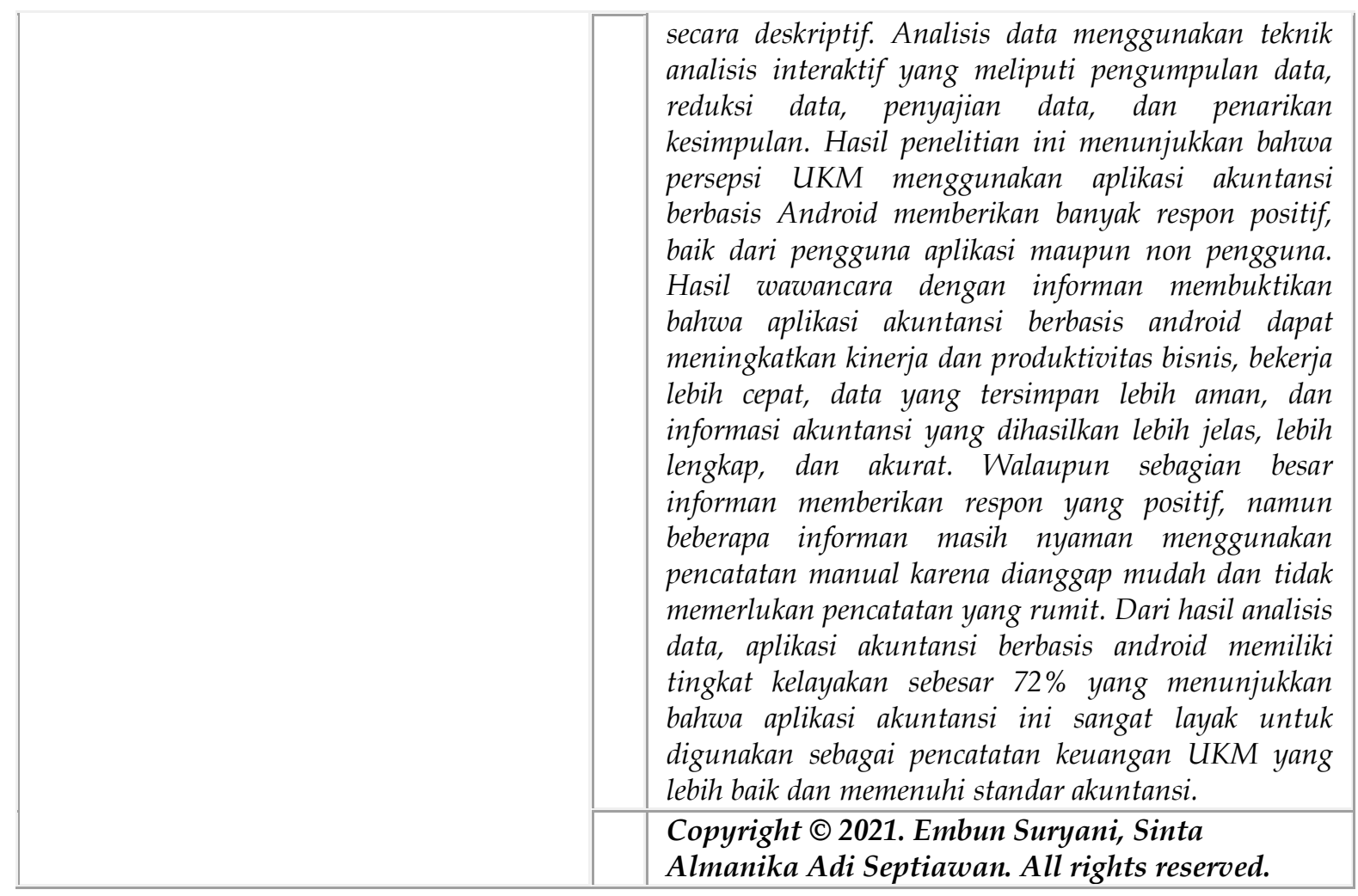

\section{LATAR BELAKANG}

UKM memiliki peran penting dan strategis dalam pembangunan ekonomi nasional. Selain berperan di dalam pertumbuhan ekonomi serta penyerapan tenaga kerja, UKM juga berperan di dalam mendistribusikan hasil-hasil pembangunan. Selain itu, UKM juga telah terbukti tidak terpengaruh terhadap krisis ekonomi (Wijaya, 2018: 1). UKM merupakan salah satu entitas pelaku ekonomi yang eksistensinya memiliki dominasi terhadap perekonomian bangsa. Pada tahun 2018, UMKM menyumbang terhadap PDB hingga 60,34 persen, usaha kecil mikro berjumlah sekitar 93,4 persen, kemudian usaha menengah 5,1 persen, dan yang besar hanya 1 persen dari total entitas (Putra, 2018). Namun, UMKM memiliki banyak keterbatasan dan kendala, salah satunya adalah keterbatasan kemampuan dalam pengelolaan keuangan. Mayoritas UMKM tidak menerapkan pencatatan keuangan secara tepat sesuai dengan aturan yang berlaku umum yaitu standar akuntansi keuangan (Dinarti dkk, 2015).

Di satu sisi, era globalisasi yang semakin pesat dan persaingan yang semakin tajam khususnya pada dunia usaha mengakibatkan bertambahnya masalah yang dihadapi manajemen perusahaan yang secara langsung maupun tidak langsung berpengaruh terhadap situasi dan aktivitas perusahaan. Untuk itu, perusahaan hendaknya mengambil keputusan dengan cepat, tepat dan akurat. Langkah yang tepat dapat diambil oleh pimpinan perusahaan adalah bagaimana seharusnya menerapkan sistem informasi akuntansi yang baik yaitu yang dapat mengatur pelaksanaan kegiatan perusahaan dan dapat menunjang efektivitas perusahaan khususnya dalam hal pengelolaan keuangan perusahaan (Maulana, 2015). Sistem informasi akuntansi di dalam perusahaan berguna untuk mengumpulkan serta menyimpan data-data yang menyangkut aktivitas yang terjadi di dalam suatu perusahaan dan juga sebagai suatu informasi terpercaya yang dapat digunakan untuk pertimbangan dalam mengambil keputusan demi kemajuan perusahaan 
(Wijaya \& Artina, 2014). Selain itu, pencatatan keuangan UMKM memiliki peran karena merupakan salah satu syarat mendapatkan pembiayaan dari perbankan untuk mengembangan kegiatan usahanya.

Oleh sebab itu, dibutuhkan sistem informasi akuntansi yang lebih tepat, akurat, dan efektif dalam mengelola keuangan UMKM baik itu software berbasis komputer atau basis aplikasi ponsel pintar (smartphone). Perkembangan teknologi informasi, terutama pada era informasi berdampak signifikan terhadap sistem informasi akuntansi dalam suatu perusahaan. Dampak secara nyata yang dapat dirasakan adalah pemrosesan data mengalami perubahan mulai dari sistem manual ke sistem komputer. Banyak perusahaan yang mulai mengembangkan dan memberikan perhatian khusus pada teknologi informasi secara efektif. Salah satu bentuk perhatian ini adalah penggunaan sistem informasi akuntansi berbasis komputer (software akuntansi) untuk memperlancar arus informasi perusahaan (Karte, 2017). Sistem informasi akuntansi tidak hanya terbatas pada pencatatan data-data keuangan secara manual atau komputer saja. Seiring pesatnya perkembangan teknologi saat ini pencatatan data-data keuangan juga dapat dilakukan secara online atau berbasis web bahkan karena semakin berevolusinya berbagai jenis ponsel pintar (smartphone), sudah banyak diluncurkan aplikasi pencatatan keuangan berbasis mobile android untuk memudahkan para penggunanya, khususnya bagi UKM.

Kelebihan dari sistem operasi android adalah variasi merek smartphone yang beredar di pasaran, tersedia berbagai aplikasi-aplikasi permainan, pembelajaran, media sosial, keuangan dan juga tentunya akuntansi. Kesempatan bagi para pengguna aplikasi akuntansi, untuk dapat belajar dan berupaya melalui pemanfaatan teknologi sebagai peluang, untuk meningkatkan keuntungan secara maksimal (Karte, 2017). Selain penggunaannya yang mudah, ponsel pintar berbasis android mempunyai harga yang terjangkau. Bahkan banyak fitur gratis yang dikembangkan oleh pengembang aplikasi berbasis android untuk memudahkan pada pengguna android, seperti fitur keuangan dan media sosial. Fitur tersebut dapat digunakan oleh pelaku usaha untuk memudahkan operasional perusahaan dalam hal mengelola keuangan dan promosi (Elvira, 2018).

Berbagai aplikasi pencatatan keuangan basis android yang dapat digunakan oleh UMKM pada saat ini diantaranya Si Apik, Akuntansi UKM - Keuangan, LAMIKRO Akuntansi Usaha Mikro, Zahir Simply, GROW - Accounting and Invoice Online, Moka POS, dan lain sebagainya. Penggunaan aplikasi ini dapat mempercepat serta memberikan olah data yang lebih akurat dari pada manual dan seluruh kejadian dapat ditelusuri dengan lebih mudah, serta bersifat fleksibel karena dapat dilakukan di mana saja dan kapan saja. Berdasarkan hasil penelitian terdahulu membuktikan bahwa dalam pencatatan keuangan dengan menggunakan aplikasi keuangan android pada smartphone pemilik UMKM memudahkan dalam transaksi bisnis berupa pembelian-penjualan, hutang-piutang, pembayaran beban operasional dan lainnya (Ria, 2018). Selain itu penelitian yang dilakukan oleh Elvira (2018) memberikan hasil bahwa aplikasi Si Apik membantu perusahaan dalam melakukan pencatatan akuntansi serta melakukan pelaporan keuangan yang baik dan sesuai dengan aturan yang berlaku.

Berdasarkan hasil penelitian tersebut, dapat diketahui bahwa sistem pencatatan akuntansi basis android sangat membantu proses pencatatan keuangan UMKM sektor jasa, dagang, maupun manufaktur. Disamping kemudahan penggunaan dan biayanya yang relatif murah, penerapan aplikasi keuangan basis android mampu menghasilkan kualitas laporan keuangan yang akuntabel dan sesuai dengan standar akuntansi yang berlaku. Namun, pemanfaatan smartphone android sebagai pencatatan atau pengelolaan keuangan oleh UMKM masih sangat terbatas, berbanding terbalik dengan pemanfaatan smartphone android sebagai media marketing. Untuk itu, penulis tertarik untuk mengetahui bagaimana 
persepsi pengguna dan bukan pengguna aplikasi akuntansi berbasis android dengan pendekatan Technology Acceptance Model (TAM) dan theory of planned behavior (TPB).

Penelitian ini bertujuan untuk mengetahui persepsi pengguna aplikasi akuntansi berbasis android dan menilai tingkat kelayakan aplikasi apabila digunakan oleh pelaku UMKM sebagai sistem informasi akuntansinya. Peneliti merumuskan pertanyaan riset sebagai berikut: 1) bagaimanakah persepsi UMKM pengguna aplikasi terhadap aplikasi akuntansi berbasis android dengan pendekatan technology acceptance model?; 2) bagaimanakah persepsi UMKM bukan pengguna aplikasi terhadap aplikasi akuntansi berbasis android dengan pendekatan theory of planned behavior?; 3) apakah penggunaan aplikasi akuntansi berbasis android layak digunakan oleh UMKM sebagai sistem informasi akuntansinya?

\section{TINJAUAN PUSTAKA}

\subsection{Theory of Planned Behavior}

Theory of Planned Behavior atau teori perilaku terencana adalah pengembangan dari Theory of Reasoned Action (TRA). Teori ini dikemukakan oleh Ajzen (1985) dengan menambahkan sebuah konstruk yaitu persepsi kontrol keperilakuan (perceived behavioral control) yang dipersepsikan akan mempengaruhi minat dan perilaku. Konstruk ini ditambahkan di TPB untuk mengontrol perilaku individu yang dibatasi oleh kekurangankekurangannya dan keterbatasan-keterbatasan dari kekurangan sumber daya yang digunakan untuk melakukan perilaku (Jogiyanto, 2007).

TRA menekankan perilaku yang rasional yaitu perilaku dimana individu memiliki kontrol. Pada penelitian yang dilakukan oleh Sheppard (1988) TRA tidak dapat menutupi faktor yang mempengaruhi terjadinya suatu perilaku. Dengan pertimbangan tersebut peneliti menggunakan TPB sebagai dasar teori untuk menentukan faktor yang mempengaruhi intensi. Theory of Planned Behavior (TPB) adalah ekstensi dari Theory of Reasoned Action (TRA). TPB dirancang untuk menentukan dan mengetahui perilaku konsumen yang lebih spesifik (Ajzen, 1991). Konsep Theory of Planned Behavior menjelaskan bahwa suatu perilaku akan dilakukan jika individu memiliki keinginan ataupun rencana untuk melakukannya. Semakin kuat keinginan tersebut, maka akan semakin kuat niat tersebut untuk menampilkan suatu perilaku (Jogiyanto, 2007:29).

\subsection{Technology Acceptance Model (TAM)}

Ketika menjalankan sistem komunikasi dan transaksi yang memanfaatkan teknologi sebagai media seseorang akan dihadapkan pada pemilihan keputusan yang sulit karena akan menanggung resiko apabila terdapat kegagalan dari sistem tersebut. Perilaku manusia untuk menerima suatu teknologi sebagai sebuah alat bantu harus benar-benar diuji kredibilitasnya agar dapat dimanfaatkan dalam lingkup yang luas. Sebuah teknologi dikatakan kredibel atau handal apabila memiliki prinsip Technology Acceptance Model (TAM). TAM juga menjelaskan bahwa individu dapat bebas memilih dalam menggunakan teknologi (Firladi, 2017).

Menurut Jogiyanto (2008:111) Technology Acceptance Model (TAM) atau Model Penerimaan Teknologi merupakan salah satu teori tentang penggunaan sistem teknologi informasi yang dianggap sangat berpengaruh dan umumnya digunakan untuk menjelaskan penerimaan individu terhadap penggunaan sistem teknologi informasi. Technology acceptance model merupakan sebuah model yang dikembangkan oleh Feed D. Davis pada tahun 1986 untuk menganalisis dan memahami faktor-faktor yang mempengaruhi diterimanya penggunaan teknologi informasi (Yudi, 2013). TAM pertama 
dikembangkan oleh Davis (1986) berdasarkan model Theory of Reasoned Action (TRA). TRA atau Teori Tindakan Beralasan merupakan teori perilaku manusia yang paling mendasar dan berpengaruh serta telah banyak diterapkan di beberapa bidang termasuk bidang pemasaran dan sistem informasi. TRA dikembangkan oleh Fishben dan Ajzen pada tahun 1975 (Jogiyanto, 2007:17).

TRA dapat diterapkan karena keputusan yang dilakukan oleh individu untuk menerima suatu teknologi sistem informasi merupakan tindakan sadar yang dapat dijelaskan dan diprediksi oleh minat perilakunya (Maharseni, 2018). Model TRA melibatkan beberapa konstruk. Konstruk-konstruk tersebut adalah: (1) Behavior, (2) Behavioral intention, (3) Attention toward behavior dan (4) Subjective norm (Ratri, 2016). TAM menambahkan dua konstruk utama ke dalam model TRA. Dua konstruk utama ini adalah kegunaan (perceived usefulness) dan kemudahan penggunaan (perceived ease of use). TAM berargumentasi bahwa penerimaan individu terhadap sistem teknologi informasi ditentukan oleh dua konstruk. TAM memiliki 5 konstruk utama, yaitu (1) Perceived usefulness (Kegunaan persepsi), (2) Perceived ease of use (Kemudahan penggunaan persepsian), (3) Attitude towards behavior (Sikap terhadap perilaku), (4) Behavioral intention (Minat pelaku), dan (5) Behavior (Perilaku).

\section{METODE PENELITIAN}

Penelitian ini menggunakan metode fenomenologi dan dianalisis secara deskriptif. Fenomenologi merupakan strategi penelitian dimana di dalamnya peneliti mengidentifikasi hakikat pengalaman manusia tentang suatu fenomena tertentu. Metode fenomenologi ini termasuk ke dalam metode penelitian kualitatif yang cenderung bersifat deskriptif dimana fenomenologi dapat memberikan peluang bagi peneliti untuk menggali informasi pengalaman manusia. Dibanding metode lain, salah satu metode yang menggunakan paradigma konstruktivistik ini lebih memberikan fleksibilitas dan kemudahan membangun konstruksi sosial realitas. Metode ini dapat memberikan informasi yang kaya atas realitas yang diteliti (Pandoyo \& Sofyan, 2018:105-106). Sedangkan analisis deskriptif yaitu data yang dikumpulkan adalah berupa kata kata, gambar, dan bukan angka-angka (Moleong, 2018:11).

Penelitian ini akan mengambil tempat atau lokasi penelitian di Kota Mataram, khususnya usaha mikro, kecil, dan menengah Kota Mataram. Metode pengumpulan data yang digunakan dalam penelitian ini menggunakan metode survey. Teknik pengumpulan data dalam penelitian ini menggunakan teknik wawancara. Proses wawancara dilakukan penulis dengan menggunakan in-depth interview secara semi-struktur (Semi Structured interview). Tujuan dari wawancara jenis ini adalah untuk menemukan permasalahan secara lebih terbuka, dimana pihak yang diajak wawancara diminta pendapat dan ide idenya (Sugiyono, 2016:233). Instrumen dalam penelitian ini adalah konstruk-konstruk dari teori yang membangun Technology Acceptance Model (TAM) dan Theory of Planned Behavior (TPB).

Dalam penelitian kualitatif, data diperoleh dari berbagai sumber, dengan menggunakan teknik pengumpulan data yang bermacam-macam (triangulasi), dan dilakukan secara terus-menerus sampai datanya jenuh (Sugiyono, 2016: 243). Proses pengumpulan data dimulai dengan menetapkan seorang informan kunci (key informant) yang dianggap representatif terhadap objek masalah dalam penelitian. Key informan dalam penelitian ini merupakan pemilik langsung atau pelaku usaha dari UMKM yang dijalankan. Karakteristik UMKM di Kota Mataram umumnya bersifat sangat homogen, sehingga indepth interview cukup dilakukan hanya pada sampel kecil, untuk itu jumlah key informan adalan 9 (sembilan) orang. Pada penelitian ini teknik analisis data dilakukan 
secara interaktif dan berlangsung secara terus menerus. Aktivitas dalam analisis data, yaitu: data reduction, data display, dan conclusion drawing/verification. Langkah terakhir dalam analisis data kualitatif adalah penarikan kesimpulan dan verifikasi.

\section{HASIL DAN PEMBAHASAN}

\subsection{Persepsi UMKM Pengguna Aplikasi Akuntansi Berbasis Android Dengan Pendekatan Technology Acceptance Model (TAM)}

TPB memiliki lima konstruk utama yang merupakan pengembangan dari konstruk TRA, tetapi pada penelitian ini peneliti hanya menggunakan empat konstruk untuk mengetahui persepsi dari pelaku UMKM bukan pengguna aplikasi akuntansi berbasis android. Lima konstruk dalam teori TPB yaitu: 1) Sikap Terhadap Perilaku (Attitude Towards Behavior); 2) Norma Subyektif (Subjective Norm); 3) Kontrol Perilaku Persepsi (Perceived Behavior Control); 4) Minat Perilaku (Behavior Intention); dan 5) Perilaku (Behavior).

\section{Sikap Terhadap Perilaku (Attitude Towards Behavior)}

Hasil wawancara dengan informan 04 WC menunjukan bahwa dengan menggunakan aplikasi akuntansi berbasis android sebagai pengelolaan keuangan akan lebih baik dibandingkan dengan menggunakan pencatatan manual. Hal tersebut sesuai dengan penuturannya berikut ini:

"Menurut saya jelas lebih bagus yang aplikasi android gitu, karena lebih cepat, mudah, dan fleksibel kita kapanpun dimanapun bisa asal kita sebenernya punya fokus ya, atau waktu untuk mengerjakannya gitu" (Wawancara 8 September 2020).

Informan 01JP membenarkan bahwa dengan menggunakan aplikasi akuntansi berbasis android meningkatkan kinerja usaha dimana aplikasi yang digunakan oleh informan 01JP meringankan pekerjaan dalam melakukan pencatatan keuangan karena dengan menggunakan aplikasi akuntansi berbasis android pelaku usaha hanya perlu melakukan satu tahapan, dimana hanya menginput transaksi pengeluaran atau pemasukan tanpa harus membuat pembukuan secara manual. Jawaban yang diberikan oleh informan 01JP sesuai dengan yang diungkapkan oleh informan 02LS, dimana 01JP dan 02LS setuju bahwa dengan menggunakan aplikasi akuntansi berbasis android memang benar dapat meningkatkan kinerja usaha karena penggunaannya yang mudah, cepat, dan dapat dipakai dimana saja sehingga lebih menghemat waktu kerja. Informan 01JP, 02LS, 03 IPC, dan 09AL memiliki persepsi yang serupa terkait dengan peningkatan kinerja usaha setelah menggunakan aplikasi akuntansi berbasis android, dimana aplikasi yang digunakan bersifat fleksibel yaitu mudah dibawa kemana-mana dan dapat dikerjakan dimana saja, lebih mudah dan cepat karena hanya tinggal menginput transaksi berupa jurnal maka sudah langsung bisa melihat output laporan keuangannya.

Namun jawaban yang diberikan oleh informan 05 MLW tidak sejalan dengan apa yang diungkapkan informan 01JP dan 02LS. 05 MWL mengatakan bahwa aplikasi akuntansi berbasis android yang digunakan tidak relevan dengan jenis usaha yang dijalankannya, yaitu usaha mutiara. Jawaban yang diungkapan oleh informan 05 MLW karena transaksi yang dimiliki usaha mutiara yang dikelola oleh informan 05 MLW kompleks dan beragam jadi aplikasi yang digunakan tidak dapat meningkatkan kinerja usahanya, malahan semakin memperumit pembukuan keuangannya.

Indikator lain yang yang berkaitan dengan kegunaan persepsian (perceived usefulness) adalah bagaimana para informan memandang aplikasi akuntansi berbasis android lebih baik dibandingkan dengan sistem pencatatan secara manual. Menurut persepsi informan 01JP, ia mengungkapkan bahwa dengan menggunakan aplikasi 
akuntansi berbasis android, data keuangan yang dimiliki tidak mudah hilang. Sedangkan apabila menggunakan sistem pencatatan secara manual data keuangan masih memiliki risiko kemungkinan tercuri, hilang, rusak, atau tidak akurat. Seperti yang diungkapkan oleh informan 02LS, bahwa aplikasi akuntansi berbasis android lebih mudah digunakan dibandingkan dengan pencatatan manual, selain itu juga mengurangi risiko salah input oleh pengguna.

Berdasarkan hasil wawancara dengan kelima informan pengguna aplikasi akuntansi berbasis android, dapat disimpulkan bahwa kelima informan menggunakan aplikasi akuntansi berbasis android sebagai sistem pencatatan keuangannya karena mereka menganggap bahwa aplikasi yang digunakan memberikan manfaat berupa peningkatan kinerja pengelola keuangan dan lebih efektif dibandingkan dengan pencatatan keuangan manual, meskipun tidak meningkatkan output produksinya. Sehingga dikatakan bahwa aplikasi akuntansi berbasis android memenuhi konstruk kegunaan persepsian (perceived usefulness) sebab mempengaruhi minat UMKM dalam menggunakan aplikasi tersebut.

\subsubsection{Kemudahan Penggunaan Persepsian (Perceived Ease of Use)}

Pertanyaan yang diajukan peneliti berkaitan dengan konstruk kemudahan penggunaan persepsian (perceived ease of use) adalah persepsi kemudahan aplikasi apabila digunakan oleh pemula dan persepsi kemudahan dari segi menu dan istilah-istilah pada aplikasi, apakah bisa dipahami secara langsung oleh penggunanya tanpa harus mempelajari lebih dalam apa saja akun-akun pada akuntansi.

Berdasarkan jawaban yang diberikan oleh informan 01JP terkait pertanyaan tentang kemudahan aplikasi akuntansi berbasis android apabila digunakan oleh pemula, informan 01JP menjawab aplikasi yang digunakan sangat mudah karena akun atau itemitem yang ada bisa diubah sesuai kehendak penggunanya, terutama apabila ada akun yang sulit dipahami. Berikut hasil wawancara dengan informan 01JP:

"Menurut saya aplikasi yang saya gunakan itu akunnya itu bisa kita ubah sendiri. Jadi seperti yang saya bilang tadi, karena kan kita ini usahanya bisa dibilang masih kategori kecil jadi akunnya tidak seribet perusahaan. Jadi akun-akunnya bisa kita buat sendiri, seperti persediaan gelas, seperti biaya beli es batu segala macam yang mungkin tidak ada di akun-akun perusahaan besar. Jadi untuk pemula ini sangat bagus sekali, sangat baik sekali" (Wawancara 20 Agustus 2020).

Namun, jawaban lain diberikan oleh informan 03 IPC yang juga menggunakan aplikasi sejenis dengan informan 02LS, bahwa aplikasi yang digunakan ternyata tidak langsung mudah dipahami oleh semua pelaku UMKM. Informan 03 IPC merupakan seorang ibu rumah tangga yang berlatar belakang pendidikan sarjana manajemen. Ia mengatakan bahwa meskipun aplikasi akuntansi berbasis android yang digunakan saat ini dalam hal penginputan sangat mudah digunakan, namun untuk istilah-istilah pada menu atau output laporan keuangan harus dipelajari terlebih dahulu untuk bisa menafsirkan dan menjelaskan hasil dari laporan keuangan sehingga bisa mengambil keputusan kedepannya. Berdasarkan beberapa persepsi pelaku UMKM di atas, bahwa dalam hal penginputan transaksi keuangan, aplikasi akuntansi berbasis android cukup mudah digunakan. Namun untuk memahami maksud dan pengertian dari akun-akun dan istilah dalam aplikasi akuntansi berbasis android tersebut harus dipelajari terlebih dahulu atau mendapatkan pelatihan khusus akuntansi. Sehingga peneliti menyimpulkan dalam hal kemudahan penggunaan mulai dari mengunduh software aplikasi dari playstore, membuat akun dengan memasukkan data dan profil usaha, hingga melakukan input transaksi sebenarnya aplikasi akuntansi berbasis android telah memenuhi konstruk kemudahan penggunaan dalam teori technology acceptance model. Hanya saja pengetahuan wajib yang harus dimiliki oleh pelaku UMKM adalah menguasai dasar-dasar akuntansi untuk dapat mempertanggungjawabkan dan mengevaluasi perkembangan usahanya. 


\subsubsection{Sikap Menggunakan Teknologi (Attitude Towards Using)}

Pertanyaan yang diajukan peneliti berdasarkan konstruk sikap menggunakan teknologi (attitude towards using) berkaitan dengan tingkat kepercayaan pengguna aplikasi akuntansi berbasis android yang berupa penerimaan bahwa aplikasi akuntansi berbasis android penting digunakan sebagai sistem informasi akuntansi UMKM, alasan memilih aplikasi akuntansi berbasis android sebagai sistem informasi akuntansi dan kelebihan yang ditawarkan aplikasi. Hasil wawancara dengan informan 01JP yang mengungkapkan bahwa aplikasi akuntansi berbasis android penting digunakan untuk pelaku UMKM khususnya usaha yang dimilikinya. Karena hasil informasi laporan keuangan dari aplikasi akuntansi yang digunakan saat ini dianggapnya mengandung salah satu karakteristik kualitatif laporan keuangan, yaitu andal (reliable) karena dapat dipertanggungjawabkan, seperti penuturannya berikut ini:

"Menurut saya penting, penting. Untuk usaha yang saya geluti sangat penting, karena asas akuntansi itu adalah salah satunya andal, andal itu dapat dipercaya dapat dipertanggungjawabkan. Jadi aplikasi ini sangat membantu untuk asas andal tersebut, jadi pelaporannya itu bisa sangat dipercaya karena menggunakan aplikasi" (Wawancara 20 Agustus 2020).

Selain itu, hasil wawancara dengan informan 03 IPC dan 05 MLW memberikan jawaban serupa, bahwa aplikasi akuntansi berbasis android penting digunakan untuk memberikan pencatatan terpisah antara uang pribadi dan uang usaha, agar jelas catatan pengeluaran dan pendapatan usaha sehingga akan jelas pula laba atau rugi yang didapat. Informan 05 MLW juga mengungkapkan kelebihan dari aplikasi yang digunakan dibanding dengan aplikasi yang lain sehingga bertahan lama menggunakan aplikasi tersebut.

Berdasarkan hasil wawancara dengan lima informan pengguna aplikasi akuntansi berbasis android, kelima informan memberikan respon positif atau menerima aplikasi tersebut sebagai sistem informasi akuntansinya karena mempunyai perasaan bahwa aplikasi tersebut akan membantu menyelesaikan pelaporan keuangan dengan baik. Respon positif dari pelaku UMKM mempengaruhi minat mereka dalam menggunakan aplikasi akuntansi berbasis android yang kemudian juga berpengaruh terhadap perilaku atau tindakan yang diambil. Kelima informan memiliki persepsi serupa bahwa aplikasi akuntansi berbasis android penting digunakan pelaku UMKM dengan berbagai macam alasan, seperti pelaporan keuangannya yang lebih jelas dan kredibel sehingga minim dari risiko kesalahan, manajemen keuangan yang baik untuk pengambilan keputusan yang tepat, serta sebagai pemisah dan pembeda antara uang pribadi dan usaha usaha.

\subsubsection{Minat Perilaku Menggunakan Teknologi (Behavior Intention to Use)}

Hasil wawancara dengan informan 01JP mengungkapkan bahwa saat ini ia masih menggunakan aplikasi akuntansi berbasis android sebagai pencatatan keuangannya. Untuk rencana penggunaan aplikasi kedepannya informan 01JP mengungkapkan keinginannya untuk mengganti aplikasi akuntansi berbasis android dengan yang lebih baik lagi namun masih berbasis android karena fleksibel digunakan dimana saja. Informan 02LS dan 03 IPC hingga saat ini masih bertahan menggunakan aplikasi yang sama sebagai sistem informasi akuntansi, namun diakui keduanya apabila ada aplikasi yang lebih baik lagi mereka akan mengganti aplikasi yang lama untuk mendapatkan hasil pencatatan dan laporan yang lebih baik lagi.

Namun informan lain ada juga yang tidak bertahan menggunakan aplikasi akuntansi berbasis android dan saat ini telah kembali menggunakan pencatatan manual, seperti informan 05 MLW karena diakuinya tidak bisa memenuhi keinginan dari jenis usaha yang dijalankan. Saat ini informan 05 MLW masih menggunakan pencatatan manual 
setelah 4 bulan lamanya bertahan menggunakan aplikasi akuntansi berbasis android. Berikut kendala menggunakan aplikasi akuntansi berbasis android dan alasan informan 05 MLW kembali menggunakan basis manual. Terlepas dari kendala dan alasan informan 05 MLW berhenti menggunakan aplikasi akuntansi berbasis android, namun informan 05 MLW mengungkapkan rencananya menggunakan aplikasi berbasis android kembali namun dengan mempekerjakan tenaga akuntan untuk mengambil alih tanggung jawab pengelolaan keuangannya yang selama ini masih dikerjakan sendiri.

Sehingga dapat disimpulkan bahwa empat dari lima informan pengguna aplikasi akuntansi berbasis android, saat ini masih bertahan menggunakan aplikasi yaitu informan 01JP, 02LS, 03 IPC, dan 09AL, sedangkan informan 05 MLW memilih untuk kembali menggunakan pencatatan secara manual dengan alasan aplikasi yang digunakan tidak dapat memenuhi kebutuhan pencatatan transaksi usahanya. Perubahan minat dalam menggunakan aplikasi akuntansi berbasis android oleh informan 05 MLW dari basis android menjadi manual, sesuai dengan konsep dari konstruk minat dimana menunjukkan bahwa minat tidak selalu statis dan dapat berubah dengan berjalannya waktu. Sedangkan untuk rencana penggunaan aplikasi di masa depan, kelima informan setuju akan tetap menggunakan aplikasi akuntansi berbasis android tentunya mereka akan mengganti sistem sekarang ke sistem yang lebih baik lagi dengan aplikasi yang berbeda seiring dengan perkembangan teknologi dan usahanya.

\subsubsection{Penggunaan Teknologi Sesungguhnya (Actual Technology Use)}

Perilaku (behavior) adalah tindakan yang dilakukan oleh seseorang. Dalam konteks penggunaan sistem teknologi informasi, perilaku (behavior) adalah penggunaan sesungguhnya (actual use) dari teknologi. Davis (1989) menggunakan pengukuran pemakaian sesungguhnya (actual usage), dan Igbaria et al. (1995) menggunakan pengukuran pemakai persepsian (perceived usage) yang diukur sebagai jumlah waktu yang digunakan untuk berinteraksi dengan suatu teknologi dan frekuensi penggunaannya (Jogiyanto, 2007: 117). Pertanyaan yang diajukan dalam penelitian ini yang berkaitan dengan konstruk penggunaan teknologi sesungguhnya (actual technology use) adalah perubahan pencatatan keuangan pengguna aplikasi dari manual menjadi aplikasi berbasis android dan seberapa sering pengguna melakukan input transaksi bisnis menggunakan aplikasi tersebut.

Hasil wawancara dengan informan 01JP mengungkapkan bahwa informan 01JP memiliki perubahan drastis terhadap sistem informasi akuntansinya. Ia mengatakan bahwa selama menggunakan sistem pencatatan keuangan manual, data keuangan yang tercatat sering tidak sama dengan realisasinya. Berbeda dengan setelah menggunakan aplikasi akuntansi berbasis android dimana pencatatan dengan realisasi uang yang dimiliki selalu sama. Pernyataan senada diungkapkan oleh informan 02LS bahwa aplikasi akuntansi berbasis android membawa perubahan terhadap pengelolaan keuangannya. Diakui bahwa aplikasi yang digunakan fleksibel dan mudah digunakan dimana saja. Selain itu juga lebih menghemat biaya persediaan karena tidak perlu menyediakan alat tulis untuk melakukan pencatatan keuangan. Hal yang sama diungkapkan oleh informan 03 IPC dan 09AL. Selain itu, kelima informan juga mengakui bahwa rutin melakukan input transaksi keuangan ke dalam aplikasi setiap ada pengeluaran atau pemasukan. Pernyataan serupa juga diakui oleh keempat informan lainnya bahwa mereka melakukan pencatatan dengan menggunakan aplikasi akuntansi berbasis android setiap kali ada transaksi pengeluaran dan pemasukan.

Berdasarkan hasil wawancara dengan kelima informan pengguna aplikasi akuntansi berbasis android tersebut, didapat hasil bahwa setelah menggunakan aplikasi berbasis android, pengelolaan keuangan pelaku UMKM menjadi lebih baik sebab fleksibel 
digunakan dimana saja, menghemat biaya persediaan, serta lebih akurat karena pencatatan pengeluaran dan pemasukan sesuai dengan realisasi uang yang dimiliki pelaku UMKM.

Selain itu manfaat lain yang dirasakan informan adalah lebih mampu memanajemen uang usaha yang dimiliki dengan memilah mana pengeluaran yang harus diutamakan dan tidak. Pertanggungjawaban kepada pihak eksternal juga penting bagi pelaku UMKM apabila akan mengajukan pendanaan untuk pengembangan usahanya sehingga dengan menggunakan aplikasi berbasis android pihak eksternal akan lebih yakin dan percaya sebab pelaku UMKM memiliki penyajian laporan keuangan yang baik berdasarkan kaidah ilmu akuntansi yang memiliki bahasa yang standar sehingga dapat dipahami oleh pihak lain. Selain itu, laporan keuangan yang sesuai kaidah akuntansi memudahkan pelaporan kepada kantor pajak. Intinya, dengan menggunakan pencatatan basis android pelaku UMKM dapat mempertanggungjawabkan segala aktivitas usahanya.

\subsection{Persepsi UMKM Bukan Pengguna Aplikasi Akuntansi Berbasis Android dengan Pendekatan Teori Theory of Planned Behavior (TBP)}

Adapun konstruk perilaku (behavior) tidak digunakan dalam penelitian ini karena perilaku (behavior) dalam konteks penggunaan sistem teknologi informasi merupakan penggunaan sesungguhnya (actual use) jadi tidak sesuai dengan informan karena informan bukan pengguna aplikasi akuntansi berbasis android. Bagian ini akan menjelaskan persepsi UMKM bukan pengguna aplikasi akuntansi berbasis android terkait bagaimana pendapat mereka dengan penggunaan aplikasi akuntansi berbasis sebagai sistem informasi akuntansi dalam kegiatan usahanya. Pertanyaan diajukan kepada informan yang merupakan pelaku UMKM bukan pengguna aplikasi akuntansi berbasis android tetapi mengenal sedikitnya satu aplikasi akuntansi berbasis android.

\subsubsection{Sikap Terhadap Perilaku (Attitude Towards Behavior)}

Pada penelitian ini konstruk sikap (attitude) peneliti kaitkan dengan kepercayaan bahwa aplikasi akuntansi berbasis android sebagai sistem informasi akuntansi perusahaan dapat meningkatkan kinerja usaha pelaku UMKM sehingga dapat menyelesaikan pekerjaan pencatatan keuangan dengan cepat. Hasil wawancara dengan informan 04 WC menunjukan bahwa dengan menggunakan aplikasi akuntansi berbasis android sebagai pengelolaan keuangan akan lebih baik dibandingkan dengan menggunakan pencatatan manual. Selain itu dibandingkan dengan pencatatan keuangan, aplikasi akuntansi berbasis android juga langsung menyediakan laporan keuangan yang sesuai dengan standar dan kaidah akuntansi yang berlaku umum. Sedangkan pencatatan secara manual harus mempelajari terlebih dahulu teori akuntansi atau memiliki akuntan tersendiri untuk dapat membuat laporan keuangan yang sesuai dengan kaidah dan standar akuntansi.

Pernyataan bertolak belakang diungkapkan oleh informan 07 PL dan 06BA yang masih percaya bahwa pengelolaan keuangan secara manual lebih baik dibandingkan dengan menggunakan aplikasi akuntansi berbasis android. Diakui informan 07 PL bahwa ia lebih nyaman melakukan pencatatan secara manual sebab pencatatan yang penting menurutnya adalah pengeluaran dan penjualan, karena itu ia tidak membutuhkan aplikasi lain. Sedangkan informan 06BA mengungkapkan bahwa saat ini sudah nyaman dan tidak ada masalah atau kendala selama menggunakan pencatatan secara manual, namun ia mengakui bahwa secara teknis sistem keuangan pencatatan berbasis android sudah pasti memberikan berbagai kemudahan seperti penuturannya berikut:

Terlepas dari menggunakan aplikasi berbasis android atau manual, informan 07 PL dan 06BA mengakui dan menyadari bahwa aplikasi akuntansi berbasis android akan meningkatkan kinerja usaha karena alasan yang sama dengan informan 04 WC dan 08BS yaitu menghemat waktu kerja, mudah digunakan, serta fleksibel digunakan dimana saja. 
Sehingga dapat disimpulkan bahwa keempat informan memiliki kepercayaan bahwa dengan menggunakan aplikasi akuntansi berbasis android dapat meningkatkan kinerja usaha. Sedangkan dua dari empat informan yaitu informan 04 WC dan 08BS mengakui dan meyakini bahwa dengan menggunakan aplikasi akuntansi berbasis android akan lebih memudahkan pengelolaan keuangan pelaku UMKM, sedangkan informan 07 PL dan 06BA menganggap bahwa pencatatan keuangan secara manual tidak kalah baik dengan menggunakan aplikasi selama pelaku UMKM sudah terbiasa dan tidak mengalami kendala dalam melakukan pencatatan. Berdasarkan konsep dari sikap terhadap perilaku dalam teori perilaku rencanaan (theory planned of behavior) kepercayaan terhadap aplikasi akuntansi berbasis android yang diungkapkan oleh informan akan memproduksi sikap menyukai atau tidak menyukai terhadap aplikasi akuntansi berbasis android. Bisa jadi kelima informan menyukai atau memberikan perspektif positif tentang aplikasi akuntansi berbasis android sehingga memiliki minat (behavioral intention) untuk menggunakan aplikasi, tetapi dari perspektif dan minat tersebut belum tentu akan memproduksi suatu perilaku (behavior) atau tindakan dalam menggunakan aplikasi.

\subsubsection{Norma Subyektif (Subjective Norm)}

Norma subyektif dalam teori TPB merupakan kepercayaan yang mengarahkan tindakan manusia yang disebut kepercayaan-kepercayaan normatif (normative beliefs), yaitu kepercayaan tentang ekspektasi normatif dari orang orang lain dan motivasi untuk menyetujui ekspektasi tersebut (Jogiyanto, 2007: 65 - 66 ). Pada penelitian ini konstruk norma subyektif (subjective norm) peneliti kaitkan dengan pengaruh atau motivasi dari UMKM lain kepada para informan untuk menggunakan aplikasi akuntansi berbasis android. Hasil penelitian dengan informan 04 WC menunjukkan bahwa ia diperkenalkan dengan beberapa aplikasi akuntansi berbasis android oleh beberapa sumber sehingga mencoba untuk mengaplikasikannya sebagai sistem informasi akuntansi.

Jawaban dari informan 04 WC menunjukkan bahwa ia terpengaruh atau termotivasi dengan saran yang diberikan oleh pihak Bank Indonesia dan temannya sehingga memiliki kepercayaan terhadap aplikasi akuntansi berbasis android serta menimbulkan minat untuk mencoba menggunakan aplikasi tersebut. Jawaban serupa diungkapkan oleh informan 08BS. Ia mengungkapkan bahwa pernah diperkenalkan dan mendapat pelatihan menggunakan aplikasi akuntansi berbasis android oleh Bank Indonesia, dan pernah mencoba menggunakan.

Terkendala biaya informan 08BS tidak melakukan perpanjangan masa aktif aplikasi dan hanya mencoba menggunakan selama 14 hari (trial). Dari pelatihan yang diberikan oleh Bank Indonesia, informan 08BS termotivasi untuk menggunakan aplikasi berbasis android yang disarankan dan menunjukkan minat untuk menggunakan aplikasi. Sama halnya dengan informan 06BA yang juga disarankan oleh Bank Indonesia untuk menggunakan aplikasi akuntansi berbasis android sejenis dengan yang ditawarkan kepada informan 04 WC dan 08BS. Hanya saja informan 06BA tidak memiliki minat untuk menggunakan aplikasi yang disarankan karena sudah merasa nyaman dengan pengelolaan keuangan yang digunakan saat ini. Selain itu juga informan 06BA merasa terbebani apabila harus membayar aplikasi setiap bulannya.

Berdasarkan pengakuan para informan, setelah mendapat saran atau pelatihan penggunaan aplikasi akuntansi berbasis android, tidak semua informan langsung memiliki minat untuk menggunakan aplikasi tersebut, tetapi mereka mempertimbangkan dari berbagai aspek seperti misalnya biaya dan waktu yang akan dihabiskan untuk menggunakan aplikasi, serta positif dan negatifnya akibat dari penggunaan aplikasi yang disarankan. 
Ini menunjukkan bahwa informan akan berperilaku berbeda terhadap kepercayaan-kepercayaan normatif. Seperti informan 06BA misalnya, ia tidak mudah dipengaruhi dengan ekspektasi ekspektasi normatif dari pihak yang menawarinya menggunakan sistem berbasis android tetapi tetap konsisten dengan sistem yang digunakan saat ini.

Disisi lain informan 04WC, 08BS, dan 07PL bahkan sampai mencoba menggunakan aplikasi berbasis android disebabkan oleh kepercayaan normatif yang diberikan pihak Bank Indonesia. Namun karena mereka dihadapkan dengan kendala dan halangan berupa biaya aplikasi setiap bulan yang harus ditanggung, sehingga semakin lama kepercayaan normatif yang dimiliki sejak lama semakin berkurang. Sehingga norma subjective (subjective norm) bisa jadi mempengaruhi minat perilaku (behavior intention) bisa juga tidak seperti kasus pada keempat informan tersebut.

\subsubsection{Kontrol Perilaku Persepsi (Perceived Behavior Control)}

Kontrol perilaku persepsian (perceived behavior control) dalam teori TPB merupakan kepercayaan-kepercayaan kontrol (control beliefs), yaitu kepercayaan tentang keberadaan faktor-faktor yang akan memfasilitasi atau merintangi kinerja dari perilaku dan kekuatan persepsian dari faktor-faktor tersebut (Jogiyanto, 2007: 66). Pada penelitian ini konstruk control perilaku (perceived behavior control) peneliti kaitkan dengan kekhawatiran bahwa pelaku UMKM tidak dapat melakukan pengelolaan keuangan menggunakan aplikasi akuntansi berbasis android disebabkan karena suatu kendala atau hambatan.

Hasil wawancara dengan informan 04 WC mengungkapkan alasannya tidak menggunakan aplikasi akuntansi berbasis android karena kekurangan waktu dan tenaga akuntan, sehingga belum dapat dimanfaatkan secara optimal. Jawaban lain diberikan oleh informan 08 BS yang mengaku bahwa alasan utama penggunaan aplikasi berasal dari pelaku usaha itu sendiri untuk rutin dan mau menggunakan aplikasi akuntansi berbasis android. Lain halnya dengan informan 06BA yang memiliki jawaban berbeda dengan informan $04 \mathrm{WC}$ dan 08BS. Ia mengatakan bahwa alasan saat ini belum menggunakan aplikasi akuntansi berbasis android karena masih memiliki kepercayaan terhadap sistem pencatatan manual yang digunakan. Selain itu diakui bahwa selama ini tidak ada kendala dan masalah dalam menggunakan pencatatan secara manual.

Pernyataan serupa diungkapkan pula oleh informan 07 PL bahwa ia masih nyaman dengan pencatatan keuangan secara manual. Selain itu informan 07 PL juga menggunakan aplikasi kasir milik salah satu ojek online sehingga menganggap bahwa penjualan yang didapat sudah cukup jelas pencatatannya dengan menggunakan aplikasi tersebut meskipun informan 07 PL harus tetap melakukan pencatatan keuangan lagi untuk melihat total penjualan dan pengeluarannya.

Kendala dan hambatan yang mempengaruhi minat informan dalam menggunakan aplikasi akuntansi berbasis android berhubungan dengan faktor internal pelaku UMKM itu sendiri, tidak berkaitan dengan perasaan negatif yang akan diterima apabila menggunakan aplikasi akuntansi berbasis android. Para informan tidak memiliki kepercayaan atau perasaan negatif akan aplikasi akuntansi berbasis android, malah memberikan respon yang baik dan sadar akan kemudahan-kemudahan yang ditawarkan. Sehingga perlu kesadaran dari diri sendiri pelaku UMKM untuk kemudian merasa butuh dan konsisten menggunakan pencatatan akuntansi berbasis android.

\subsubsection{Minat Perilaku (Behavioral Intention)}

Secara keseluruhan dalam teori TPB, kepercayaan-kepercayaan perilaku (behavioral beliefs) memproduksi suatu sikap (attitude) menyukai atau tidak menyukai terhadap perilaku, kepercayaan kepercayaan normatif (normative beliefs) menghasilkan tekanan sosial atau norma-norma subyektif, dan kepercayaan-kepercayaan kontrol (control beliefs) akan 
memberikan kontrol perilaku persepsian (perceived behavioral control). Bersama-sama, sikap (attitute) terhadap perilaku, norma-norma subyektif (subjectived norm), dan control perilaku persepsian (perceived behavioral control) akan mengakibatkan minat perilaku (behavioral intention) dan yang selanjutnya akan menimbulkan perilaku (behavior) (Jogiyanto, 2007: 66). Konstruk minat perilaku (behavioral intention) pada penelitian ini peneliti kaitkan dengan rencana informan untuk menggunakan aplikasi akuntansi berbasis android di masa depan sebagai sistem informasi akuntansinya.

Hasil wawancara dengan informan 04 WC mengungkapkan memiliki rencana untuk menggunakan aplikasi akuntansi berbasis android di masa mendatang. Informan 04 WC sudah memiliki pengalaman dan pengetahuan bagaimana menggunakan aplikasi akuntansi berbasis android sebab pernah mencoba dan bahkan mendapat pelatihan. Bukan hanya informan 04 WC yang memiliki rencana penggunaan aplikasi akuntansi berbasis android di masa depan, informan 08BS juga mengungkapkan hal serupa bahwa rencananya menggunakan aplikasi karena ia sudah mendapatkan pelatihan sehingga ia hanya membutuhkan waktu untuk siap dan merasa mampu untuk menggunakan aplikasi tersebut. Alasan lain juga diungkapkan oleh informan 06BA. Ia mengatakan bahwa berencana menggunakan aplikasi apabila aplikasinya rendah biaya dan bahkan gratis dan memang diperuntukkan untuk jenis usaha mikro, kecil, dan menengah. Informan 07 PL mengungkapkan bahwa ia butuh belajar lebih bagaimana mengelola keuangan dengan baik dan dasar-dasar akuntansi, bahkan butuh pelatihan rutin dari dinas terkait, bukan hanya sekali namun berulang kali agar dapat membuat pencatatan keuangan sesuai dengan standar akuntansi yang berlaku.

Jadi dapat disimpulkan bahwa keempat informan tersebut, informan 04WC, 08BS, 07PL, dan 06BA memiliki minat dalam menggunakan aplikasi akuntansi berbasis android yang berasal dari faktor pribadi sebab memiliki kepercayaan (belief) atau perasaan (affect) positif jika harus menggunakan aplikasi akuntansi berbasis android sebagai sistem informasi akuntansinya. Namun minat tidak selalu statis. Minat dapat berubah dengan berjalannya waktu. Begitu pula dengan minat para informan. Perilaku penggunaan aplikasi sesungguhnya tidak dapat diprediksi secara akurat hanya dengan melihat minat dari pelaku UMKM tersebut.

\subsection{Kelayakan Aplikasi Akuntansi Berbasis Android sebagai Sistem Informasi Akuntansi UMKM}

Sejalan dengan peningkatan kinerja usaha, penggunaan aplikasi akuntansi berbasis android juga dipercaya enam dari sembilan informan dapat meningkatkan produktivitas usaha, sedangkan tiga informan tidak setuju bahwa menggunakan aplikasi dapat meningkatkan produktivitas usaha. Sehingga didapat persentase kelayakan aplikasi apabila dilihat dari aspek peningkatan kinerja dan produktivitas adalah masing-masing sebesar 100\% dan 67\%. Kemampuan dan kinerja aplikasi akuntansi berbasis android juga tidak diragukan lagi oleh sebagian besar informan. Tujuh dari sembilan informan percaya bahwa aplikasi akuntansi berbasis android memiliki banyak keunggulan dibandingkan dengan pencatatan keuangan secara manual. Tentu saja ini didukung dengan perkembangan teknologi yang sangat pesat saat ini sehingga waktu dan biaya yang dialokasikan pelaku UMKM untuk memanajemen keuangannya menjadi lebih hemat, sebab waktu dan biaya dalam dunia industri atau usaha sangat penting bagi pelaku usaha itu sendiri.

Tingkat kelayakan aplikasi akuntansi berbasis android apabila dibandingkan dengan pencatatan keuangan secara manual memiliki nilai sebesar $78 \%$. Aplikasi akuntansi berbasis android diakui enam informan mudah digunakan baik oleh pemula atau 
profesional. Selain itu, bahasa dan menu yang ditampilkan juga tidak membingungkan pengguna. Sedangkan tiga informan merasa bahwa menggunakan aplikasi akuntansi berbasis android harus dengan proses pembelajaran yang rutin sebab tidak semua pelaku UMKM memahami dasar-dasar akuntansi apalagi langsung bisa mengoperasikan aplikasi tanpa dituntun oleh mentor atau ahlinya. Sehingga tingkat kelayakan aplikasi apabila dinilai dari aspek kemudahan pengoperasian bagi pemula dan bahasa atau menu yang ditampilkan mudah dipahami mendapat persentase sebesar masing-masing $67 \%$ dan $56 \%$.

Selain itu, empat dari sembilan informan termotivasi untuk mencoba dan menggunakan aplikasi akuntansi berbasis android atas dorongan dari pihak eksternal. Sedangkan lima informan tidak terpengaruh dari pihak manapun melainkan memiliki kesadaran sendiri untuk menggunakan sistem pencatatan keuangan yang lebih otomatis dan terstruktur sebagai pengelolaan keuangannya. Tingkat kelayakan aplikasi apabila melihat dari penggunaan aplikasi akibat pengaruh yang ditimbulkan pihak eksternal hanya sebesar $44 \%$. Meskipun sebagian besar informan telah mencoba mengoperasikan aplikasi akuntansi berbasis android, namun tidak semua informan nyaman dan memiliki kepercayaan sepenuhnya dengan aplikasi tersebut.

Enam dari Sembilan informan masih bertahan menggunakan aplikasi atau memiliki rencana untuk menggunakannya di masa depan yang menunjukkan bahwa mereka merasakan manfaat setelah menerapkan aplikasi akuntansi berbasis android sehingga percaya dengan kinerja dan hasil dari aplikasi tersebut yang dapat diandalkan dan memudahkan penggunanya. Sedangkan tiga informan belum percaya sepenuhnya dan masih menyamakan hasil kinerja pengelola keuangan menggunakan aplikasi dan dengan melakukan pencatatan secara manual. Sehingga tingkat kelayakan aplikasi apabila dinilai dari aspek kepercayaan dari pelaku UMKM adalah sebesar 67\%. Aspek terakhir yaitu kejelasan output laporan keuangan yang dihasilkan aplikasi akuntansi berbasis android tidak diragukan oleh semua informan. Sembilan informan setuju dan memiliki persepsi serupa bahwa informasi akuntansi yang dihasilkan aplikasi jelas, dapat diandalkan, dan dapat dibuktikan kebenarannya, sebab dengan melakukan pencatatan manual pun pelaku UMKM terkadang hanya mencatat transaksi pengeluaran dan pendapatan saja tanpa membuat output laporan keuangan yang rinci untuk melihat laba ruginya. Jadi tingkat kelayakan aplikasi akuntansi dibandingkan dengan pencatatan manual apabila melihat dari aspek kejelasan informasi akuntansi yang dihasilkan adalah sebesar $100 \%$.

\section{KESIMPULAN}

1. Menurut persepsi pengguna aplikasi, aplikasi akuntansi berbasis android diakui memiliki berbagai manfaat dan keunggulan dari pencatatan keuangan manual. Diantaranya adalah dapat meningkatkan kinerja pengelola keuangan, meningkatkan produktivitas, menyelesaikan pekerjaan dengan cepat, fleksibel digunakan disegala situasi, data yang tersimpan lebih aman dan informasi yang dihasilkan lebih jelas, lengkap dan akurat.

2. Menurut persepsi bukan pengguna aplikasi, aplikasi akuntansi berbasis android juga dirasa para informan memberikan berbagai kemudahan, namun mereka masih bertahan menggunakan sistem pencatatan secara manual sebab diakui lebih nyaman, tidak rumit, tidak membutuhkan pencatatan yang kompleks cukup mencatat pengeluaran dan pendapatan saja, serta mereka perlu diberikan pelatihan secara rutin.

3. Hasil perhitungan tingkat kelayakan aplikasi akuntansi berbasis android untuk digunakan pelaku UMKM sebagai sistem informasi akuntansinya adalah sebesar $72 \%$ dengan kategori sangat layak yang menandakan bahwa aplikasi akuntansi berbasis 
android memberikan berbagai manfaat bagi penggunanya diantaranya kemudahan penggunaan, menu dan bahasa yang mudah dipahami, meningkatkan kinerja dan produktivitas usaha, fleksibel dan efisien digunakan dimana saja, serta informasi akuntansi yang dihasilkan jelas dan dapat diandalkan.

\section{REFERENSI}

Ajzen, I. (1991). Theory of Planned Behavior. Organizational Behavior and Human Decision Process, 50 , 179-211.

Bank Indonesia. (2015). Profil Bisnis Usaha Mikro, Kecil dan Menengah (UMKM). Jakarta: Lembaga Pengembangan Perbankan Indonesia.

Davis, F. (1989). Perceived Usefulness, Perceived Ease of Use, and User Acceptance of Information Technology. Management Information System Quarterly. Vol 3. No.3, 319-339.

Dinarti, Yunawati, S., \& Yuliza, A. (2015). Studi Penerapan Pencatatan Keuangan Bagi Usaha Kecil Menengah (UKM) - Studi Kasus Pada Usaha Warnet di Kota Tengah. Jurnal Akuntansi , 2.

Elvira, J. G. (2018). Analisis Penerapan Aplikasi Akuntansi Berbasis Android Si Apik untuk Memenuhi Kebutuhan Sistem Informasi Akuntansi Pada Usaha Mikro Kecil Menengah (Studi Kasus di GR Souvenir Pundong, Bantul, Yogyakarta). Skripsi Program Studi Akuntansi, Universitas Sanata Dharma

Firladi, I. H. (2017). Pengaruh Prinsip Technology Acceptance Model (TAM) Pada Aplikasi Go-Jek Terhadap Kepuasan Pelanggan. Skripsi. Fakultas Ekonomi dan Bisnis Universitas Brawijaya

Karte, A. C. (2017). Analisis Pemilihan Aplikasi Akuntansi Berbasis Android. Skripsi (112114044), 3.

Maharseni, N. W. (2018). Analisis Faktor-faktor Tingkat Penerimaan dan Penggunaan Aplikasi Akuntansi Berbasis Android menggunakan Pendekatan Technology Acceptance Model. Skripsi. Fakultas Ekonomi Universitas Sanata Dharma . https://www.materiakuntansi.com/perbedaansistem- akuntansi-manual-dankomputerisasi

Maulana, I. (2015). Analisis Perbandingan Sistem Informasi Akuntansi Secara Manual dengan Sistem Informasi Akuntansi Berbasis Komputer Dalam Hal Kualitas Informasi Laporan Keuangan. (1015260, Penyunt.) Jurnal Akuntansi, Universitas Siliwangi, Tasikmalaya .

Moleong. (2018). Metodologi Penelitian Kualitatif. Bandung: PT Remaja Rosdakarya.

Pandoyo, \& Sofyan, M. (2018). Metodologi Penelitian Keuangan dan Bisnis Teori dan Aplikasi Menggunakan Software Olah Data Eviews 9. Bogor: IN MEDIA.

Putra, D. A. (2018, Juli 6). UMKM Sumbang 60 Persen ke Pertumbuhan Ekonomi Nasional. Dipetik Maret 20, 2019, dari Liputan 6: www.google.com/amp/s/m.liputan6.com/amp/3581067/umkm-sumbang-60persen-kepertumbuhan-ekonomi-nasional

Ratri, S. M. (2016). Analisis Faktor-faktor yang Mempengaruhi Penggunaan ELearning Moodle Oleh Guru SMK Negeri 2 Yogyakarta Dengan Pendekatan Technology Acceptance Model (TAM). Skripsi. Fakultas Teknik Universitas Negeri Yogyakarta . Republik Indonesia. Undang-Undang Republik Indonesia Nomor 20 Tahun 2008 tentang Usaha Mikro, Kecil dan Menengah.

Ria, A. (2018). Analisis Penerapan Aplikasi Keuangan Berbasis Android Pada Laporan Keuangan UMKM Mekarsari, Depok. 
Sugiyono. (2016). Metode Penelitian Kuantitatif, Kualitatif, dan RED. Bandung: Alfabeta.

Wijaya, F. S., \& Artina, N. (2014). Analisis Penerapan Sistem Informasi Akuntansi Pada Usaha Kecil Menengah Roti Tiga Saudara. Jurnal Akuntansi (Jurnal 2014210026), 2.

Yudi, S. E. (2013). Analisis Pemanfaatan Teknologi Informasi Menggunakan Pendekatan Innovation and Diffusion Theory (IDT) dan Technology Acceptance Model (TAM) pada Disdikpora Kota Salatiga. Jurnal. Fakultas Teknologi Informasi Universitas Kristen Satya Wacana, 1-18. Jurnal. Fakultas Teknologi Informasi Universitas Kristen Satya Wacana , 1-18. 